\title{
HUBUNGAN SELF EFFICACY DENGAN KEPATUHAN MINUM OBAT PADA PENDERITA HIPERTENSI DI WILAYAH KERJA PUSKESMAS TEJAKULA 1
}

\author{
(The Correlation Between Self-efficacy and Compliance in Taking Medication for \\ Patients with Hypertension in the Work Area of Tejakula 1 Health Center) \\ Sang Ayu Kadek Sukmaningsih ${ }^{1)}$, G. Nur Widya Putra ${ }^{2)}$, Hari Sujadi ${ }^{3)}$, Putu Windi \\ Ridayanti $^{4}$ \\ Program Studi S1 Keperawatan, Sekolah Tinggi Ilmu Kesehatan Buleleng \\ e-mail: Suksma20199@gmail.com
}

\begin{abstract}
ABSTRAK
Hipertensi adalah suatu keadaan dimana seseorang mengalami peningkatan tekanan darah diatas normal yang mengakibatkan peningkatan angka kesakitan (morbiditas) dan angka kematian/ mortalitas. Hipertensi dapat diobati dengan cara patuh mengkonsumsi obat anti hipertensi. Kepatuhan minum obat dapat terjadi jika penderita memiliki keyakinan untuk sembuh, keyakinan ini dinamakan self efficacy. Tujuan dari penelitian ini adalah untuk mengetahui hubungan self efficacy dengan kepatuhan minum obat penderita hipertensi di Wilayah Kerja Puskesmas Tejakula 1. Jenis penelitian ini adalah non-eksperimental korelasional dengan uji Spearman Rank yang dilaksanakan di Wilayah Kerja Puskesmas Tejakula 1. Pengumpulan data menggunakan kuisioner kepatuhan minum obat dan kuesioner self efficacy dengan sampel 56 orang. Dari hasil penelitian didapatkan mayoritas responden memiliki tingkat kepatuhan minum obat tinggi dan memiliki self efficacy tinggi yaitu sebanyak 22 orang (39,3\%). Hasil uji analisis didapatkan nilai $p$-value 0,025 yang berarti terdapat Hubungan Self efficacy dengan Kepatuhan Minum Obat Penderita Hipertensi di Wilayah Kerja Puskesmas Tejakula 1.
\end{abstract}

Kata Kunci: Self efficacy, kepatuhan minum obat, hipertensi

\begin{abstract}
Hypertension is a condition where a person experiences an increase in blood pressure above normal which results in an increase in morbidity (morbidity) and mortality / mortality. Hypertension can be treated by way of dutifully taking anti-hypertensive drugs. Compliance with taking medication can occur if the patient has the confidence to recover, this belief is called self efficacy. The purpose of this study is to determine the correlation of Self efficacy with Compliance in Taking Medication in Patients with Hypertension in the Work Area of Tejakula 1 Health Center. This type of research is a non-experimental correlational with Spearman Rank test conducted in the Tejakula 1 Community Health Center. The data collection using medication compliance questionnaire and self efficacy questionnaire with a sample of 56 people. From the results of the study it was found that the majority of respondents had high levels of medication adherence and had high self efficacy as many as 22 people (39.3\%). The analysis test results obtained p-value of 0.025 which means that there is a correlation between of Self efficacy with Compliance in Taking Medication for Patients with Hypertension in the Work Area of Tejakula 1 Health Center.
\end{abstract}

Keywords: Self efficacy, compliance with medication, hypertension

\section{PENDAHULUAN}

Hipertensi adalah suatu keadaan dimana seseorang mengalami peningkatan tekanan darah diatas normal yang mengakibatkan peningkatan angka kesakitan (morbiditas) dan angka kematian/ mortalitas. Tekanan darah $140 / 90 \mathrm{mmHg}$ didasarkan pada dua fase 
dalam setiap denyut jantung yaitu fase sistolik 140 menunjukan fase darah yang sedang dipompa oleh jantung dan fase diastolik 90 menunjukkan fase darah yang kembali ke jantung (Triyanto, 2014:7).

Prevalensi hipertensi di Indonesia berdasalkan hasil Riskesdas 2013 pada umur $\geq 18$ tahun sebesar 25,8 $\%$, dimana daerah yang tertinggi mengalami hipertensi adalah Bangka Belitung (30,9\%), diikuti Kalimantan Selatan $(30,8 \%)$, Kalimantan Timur $(29,6 \%)$ dan Jawa Barat $(29,4 \%)$. Sedangkan, prevalensi masyarakat umur $\geq 18$ tahun yang mengalami hipertesi di Bali sebanyak 19,9\% (Badan Penelitian dan Pengembangan Kesehatan Kementerian Kesehatan RI, 2013).

Hipertensi dapat dicegah dengan pengaturan pola makan yang baik dan aktivitas fisik yang cukup. Hindari kebiasaan lainnya seperti merokok dan mengkonsumsi alkohol. Karena hal tersebut diduga berpengaruh dalam meningkatkan resiko hipertensi walaupun mekanisme timbulnya belum diketahui pasti (Shadine, 2010:30).

$$
\text { Pengobatan }
$$

dengan

antihipertensi diberikan jika modifikasi gaya hidup tidak berhasil. Dokter memiliki alasan dalam memberikan obat mana yang sesuai dengan kondisi pasien saat menderita hipertensi. Tujuan pengobatan hipertensi untuk mencegah morbiditas dan mortalitas akibat tekanan darah tinggi. Penderita hipertensi diharapkan agar patuh mengkonsumsi obat hipertensi sesuai dengan dosis yang telah diberikan oleh dokter (Shadine, 2010:30).

Kepatuhan adalah hal yang sangat penting dalam perilaku hidup sehat. Kepatuhan minum obat adalah mengkonsumsi obat-obatan yang diresepkan dokter pada waktu dan dosis yang tepat. Pengobatan hanya akan efektif apabila pasien mematuhi aturan dalam penggunaan obat (Dhewi et al., 2012)
Faktor yang mempengarui perilaku kepatuhan pasien dalam minum obat adalah faktor predisposing meliputi pengetahuan, kepercayaan, keyakinan, nilai-nilai, sikap; faktor enabling meliputi ketersediaan sarana atau fasilitas kesehatan; dan faktor reinforcing yaitu dukungan keluarga dan sikap petugas kesehatan. Kepatuhan minum obat dapat terjadi jika penderita memiliki keyakinan untuk sembuh, keyakinan ini dinamakan self efficacy (Dhewi et al., 2012).

Self efficacy dalam istilah umum disebut juga dengan keyakinan diri seseorang mengenai kemampuan dirinya dalam menjalankan tugas tertentu dan kemampuan untuk mempersuasi keadaan atau merasa percaya diri dengan perilaku sehat yang dilakukan. Teori perubahan perilaku kesehatan yang dikembangkan meletakkan adanya keyakinan diri individu terhadap tindakan medis atau kesehatan yang telah didapatkan. Self efficacy merupakan hal yang berguna dalam memproteksi kesehatan dan merupakan hal yang penting sebagai kontrol dari faktor-faktor perilaku sehat (Putu \& Rastiti, 2019).

Hasil studi pendahuluan yang dilakukan pada tanggal 18 November 2019 di Puskesmas Tejakula I didapatkan penyakit hipertensi menempati urutan pertama dalam 10 besar jenis penyakit yang berada pada Puskesmas Tejakula I. Data penderita hipertensi dari bulan Juli - September didapatkan sebanyak 75 orang, diantaranya laki-laki 32 orang dan perempuan 43 orang. Berdasarkan hasil pengkajian menggunakan kuesioner self efficacy dan kuesioner kepatuhan minum obat yang dilakukan terhadap 10 orang penderita hipertensi secara acak didapatkan 5 orang $(50 \%)$ mengalami self efficacy rendah, 2 orang (20\%) mengalami self efficacy sedang, 2 orang (20\%) mengalami self efficacy tinggi dan 1 orang (10\%) mengalami self 
efficacy sangat tinggi. Berdasarkan kuesioner kepatuhan minum obat, didapatkan bahwa 5 orang $(50 \%)$ mengalami tingkat kepatuhan rendah, 3 orang $(30 \%)$ mengalami tingkat kepatuhan sedang, 1 orang $(10 \%)$ mengalami tingkat kepatuhan tinggi, dan 1 orang (10\%) lainnya dalam kategori tingkat kepatuhan sangat tinggi.

Berdasarkan uraian di atas peneliti tertarik untuk menliti tentang "Hubungan Self Efficacy dengan Kepatuhan Minum Obat Pasien Hipertensi di Wilayah Kerja Puskesmas Tejakula 1".

\section{METODE PENELITIAN}

Penelitian ini merupakan penelitian non-eksperimental. Desain penelitian yang digunakan dalam penelitian ini adalah rancangan penelitian korelasional (hubungan/asosiasi). Penelitian korelasional bertujuan untuk mengungkapkan hubungan korelatif antar variabel. Hubungan korelatif mengacu pada kecendrungan bahwa variasi suatu variabel diikuti oleh variasi variabel yang lain (Nursalam, 2014).

Penelitian ini dilaksanakan di Wilayah Kerja Puskesmas Tejakula I dari bulan Februari 2020. Populasi dalam penelitian adalah subjek (misalnya manusia; klien) yang memenuhi kriteria yang telah ditetapkan (Nursalam, 2014). Populasi penelitian ini adalah penderita hipertensi di Wilayah Kerja Puskesmas Tejakula I yaitu sebanyak 75 orang.

Pengumpulan data dalam penelitian ini menggunakan kuesioner kepatuhan minum obat dan kuesioner self efficacy khusus hipertensi dengan jumlah sampel 65 orang. Analisa data dilakukan dengan uji Spearman Rank.

\section{HASIL PENELITIAN DAN PEMBAHASAN}

Penelitian ini menggunakan 65 sampel yang merupakan penderita hipertensi di Wilayah Kerja Puskesmas Tejakula 1 dengan karakteristik responden meliputi usia, jenis kelamin, dan riwayat pendidikan.

Tabel 1 Gambaran karakteristik responden berdasarkan usia

\begin{tabular}{cccccc}
\hline Tariabel & I & Rerata & Minimun & Maksimum & SD \\
Tisia & 56 & 45,04 & 27 & 65 & 10,694 \\
\hline
\end{tabular}

Tabel 1 menunjukkan bahwa responden memiliki usia tertinggi yaitu 65 tahun dan usia terendah 27 tahun dengan ratarata usia responden 45,04 tahun.

Tabel 2 Gambaran karakteristik responden berdasarkan jenis kelamin

\begin{tabular}{ccc}
\hline $\begin{array}{c}\text { Jenis } \\
\text { Kelamin }\end{array}$ & Frekuensi & $\begin{array}{c}\text { Persentase } \\
(\mathbf{\%})\end{array}$ \\
\hline Laki-Laki & 27 & 48,2 \\
Perempuan & 29 & 51,8 \\
\hline Total & $\mathbf{5 6}$ & $\mathbf{1 0 0}$ \\
\hline
\end{tabular}

Tabel 2 menunjukkan bahwa dari 56 responden, distribusi frekuensi responden berdasarkan jenis kelamin, mayoritas responden berjenis kelamin perempuan yaitu sebanyak 29 orang $(51,8 \%)$ dan berjenis kelamin laki-laki sebanyak 27 orang $(48,2 \%)$.

$\begin{array}{lrr}\text { Tabel } 3 & \text { Gambaran } & \text { karakteristik } \\ \text { responden } & \text { berdasarkan } & \text { riwayat } \\ \text { pendidikan } & \end{array}$

\begin{tabular}{ccc} 
pendidikan & & \\
\hline Rimayat Peadidikan & Frekuensi & Persentase (\%) \\
\hline Tidak Sedcolah & 3 & 5,4 \\
SD & 16 & 28,6 \\
SMP & 19 & 33,9 \\
SMA & 15 & 26,8 \\
Pegzuran Tingsi & 3 & 5,4 \\
\hline Total & 56 & 100 \\
\hline
\end{tabular}

Tabel 3 menunjukkan bahwa dari 56 responden, distribusi frekuensi responden berdasarkan riwayat pendidikan, mayoritas responden memiliki riwayat pendidikan SMP yaitu sebanyak 19 orang $(33,9 \%)$ dan 
minoritas memiliki riwayat pendidikan Tidak Sekolah dan Perguruan Tinggi yaitu sebanyak 3 orang $(5,4 \%)$.

Tabel 4 Karakteristik self efficacy pada responden yang mengalami hipertensi di Wilayah Kerja Puskesmas Tejakula 1

\begin{tabular}{|c|c|c|}
\hline Self efficacy & Frrikuensi & Perventase (\%) \\
\hline Sel/f pfocac Rendah & 1 & 1,8 \\
\hline Self afficacy Sedang & 12 & 21,4 \\
\hline Solf afficaxy Tingey & 3t & 55,4 \\
\hline Self offracy Sangun Tingei & 12 & 21,4 \\
\hline Tot: & 56 & 100 \\
\hline
\end{tabular}

Tabel 4 menunjukkan bahwa distribusi self efficacy responden mayoritas masuk dalam kategori self efficacy tinggi sebanyak 31 responden $(55,4 \%)$, kategori self efficacy sedang sebanyak 12 responden $(21,4 \%)$, kategori self efficacy sangat tinggi sebanyak 12 responden $(21,4 \%)$, dan sebagian kecil memiliki self efficacy rendah yaitu sebanyak 1 responden $(1,8 \%)$.

Tabel 5 Karakteristik Tingkat Kepatuhan Minum Obat pada Penderita Hipertensi di Wilayah Kerja Puskesmas Tejakula 1

\begin{tabular}{|c|c|c|}
\hline Kepatuhan Minum Obat & Frokcaeasi & Perseatase (\%) \\
\hline Kepatudan rendal & 1 & 1,8 \\
\hline Keparihan sedaug & 15 & 26,8 \\
\hline Kepatuhan tired & 32. & 97,1 \\
\hline Kegutuhas sngat tinggi & 8 & 143 \\
\hline Total & 36 & 100 \\
\hline
\end{tabular}

Tabel 5 menunjukkan bahwa distribusi kepatuhan minum obat responden mayoritas pada kategori kepatuhan tinggi yaitu sebanyak 32 responden $(57,1 \%)$, kepatuan sedang sebanyak 15 responden $(26,8 \%)$, kepatuhan sangat tinggi sebanyak 8 responden $(14,3 \%)$, dan minoritas memiliki kepatuhan rendah yaitu sebanyak 1 responden $(1,8 \%)$.

Tabel 6 Uji Spearman Rank

\begin{tabular}{lll}
\hline \multicolumn{3}{c}{ Uji Korelasi Rank Spearman } \\
\hline & Kepatuhan Minum Obat \\
\hline \multirow{2}{*}{ Self } & Conclation Coefficient & 0,299 \\
efficacy & Sig. & 0,025 \\
& $\mathrm{~N}$ & 56 \\
\hline
\end{tabular}

Tabel 6 menunjukkan bahwa nilai dari correlation coefficient sebesar 0,299 yang berarti antara self efficacy dan kepatuhan minum obat penderita hipertensi memiliki hubungan yang lemah, correlation coefficient yang bernilai positif menandakan sifat hubungan yang searah yang berarti jika self efficacy semakin tinggi maka kepatuhan minum obat juga akan semakin tinggi. Dari hasil uji statistik didapatkan nilai $p$-value 0,025 yang berarti < 0,05 sehingga antara self efficacy dengan kepatuhan minum obat penderita hipertensi di wilayah kerja Puskesmas Tejakula 1 memiliki hubungan yang signifikan.

$$
\text { Berdasarkan usia dalam }
$$

penelitian ini menunjukkan bahwa responden memiliki usia tertinggi yaitu 65 tahun dan usia terendah 27 tahun dengan rata-rata usia responden 45,04 tahun.

Menurut peneliti, usia berpengaruh terhadap kejadian hipertensi, dimana ketika seseorang menginjak usia dewasa akan memiliki banyak beban pikiran. Beban pikiran ini juka tidak teratasi dapat menimbulkan stresor, dimana stresor ini dapat memicu orang tersebut mengalami hipertensi. Selain itu, pada usia tua elastisitas pembuluh darah semakin menurun sehingga dapat memengaruhi aliran darah ke otak dan dapat memicu terjadinya hipertensi.

Hasil ini didukung oleh penelitian yang dilakukan oleh (Rusnoto \& Hermawan, 2018) dengan judul "Hubungan Stres Kerja dengan Kejadian Hipertensi pada Pekerja Pabrik di Wilayah Kerja Puskesmas Kaliwungu". Hasil dalam penelitian tersebut didapatkan bahwa dari 7 responden dengan jenis stress kerja katagori ringan, 
diperoleh sebanyak 7 (100\%) responden tidak mengalami hipertensi. Lalu dari 31 responden dengan stress kerja katagori sedang, diperoleh sebanyak $22(70.96 \%)$ responden mengalami Hipertensi dan 9 (29.03\%) responden tidak mengalami hipertensi. Hasil utama analisis didapatkan nilai $\mathrm{p}$-value 0,000 sehingga dapat disimpulkan terdapat hubungan stres kerja dengan kejadian hipertensi pada pekerja pabrik di Wilayah Kerja Puskesmas Kaliwungu.

Berdasarkan jenis kelamin dalam penelitian ini menunjukkan bahwa dari 56 responden, distribusi frekuensi responden berdasarkan jenis kelamin, mayoritas responden berjenis kelamin perempuan yaitu sebanyak 29 orang $(51,8 \%)$ dan berjenis kelamin laki-laki sebanyak 27 orang $(48,2 \%)$.

Menurut peneliti hal ini terjadi karena mayoritas dalam populasi berjenis kelamin perempuan, namun di satu sisi hal ini dapat terjadi karena peran hormon esterogen. Hormon esterogen berperan dalam proteksi tekanan darah istirahat ketika adanya aktivitas saraf simpatis otot. Pada perempuan yang berusia > 40 tahun, produksi esterogen mulai menurun, sehingga perlindungan terhadap tekanan darah ketika ada aktivitas saraf simpatis pun berkurang dan memicu terjadinya hipertensi.

Pendapat tersebut didukung oleh penelitian yang dilakukan oleh (Hilmi \& Kirnantoro, 2014) tentang "Gambaran Tingkat Stres Lansia yang Menderita Hipertensi di Gandu Sendang Tirto Berbah Selman Yogyakarta”. Hasil penelitian menunjukkan bahwa tingkat stres lebih banyak terjadi pada sampel dengan jenis kelamin perempuan dengan presentase $71,7 \%$, dan tingkat stres pada laki-laki dengan presentase $28,3 \%$.

$$
\text { Berdasarkan riwayat }
$$

pendidikan dalam penelitian ini menunjukkan bahwa dari 56 responden, distribusi frekuensi responden berdasarkan riwayat pendidikan, mayoritas responden memiliki riwayat pendidikan SMP yaitu sebanyak 19 orang $(33,9 \%)$ dan minoritas memiliki riwayat pendidikan Tidak Sekolah dan Perguruan Tinggi yaitu sebanyak 3 orang $(5,4 \%)$.

Peneliti berasumsi bahwa tingkat pendidikan mempunyai pengaruh terhadap kepatuhan minum obat penderita hipertensi, dimana semakin tinggi pendidikan seseorang memungkinkan seseorang tersebut memiliki pengetahuan yang lebih banyak dan semakin mudah pula untuk menerima informasi tentang kesehatan yang diberikan oleh tenaga kesehatan khusunya mengenai kepatuhan minum obat antihipertensi.

Hasil ini didukung oleh penelitian yang dilakukan (Ningsih \& Rosida, 2017) tentang "Faktor-Faktor yang Berhubungan dengan Kejadian Hipertensi pada Pekerja Sektor Informal di Pasar Beringharjo Kota Yogyakarta". Hasil penelitian tersebut didapatkan mayoritas responden yang berpendidikan rendah dan mengalami hipertensi yaitu sebanyak 138 orang $(76,6 \%)$ dan minoritas berpendidikan tinggi dan mengalami hipertensi yaitu sebanyak 4 orang $(2,2 \%)$. Hasil uji analisis tingkat pendidikan dengan kejadian hipertensi didapatkan nilai $p$ value 0,000 sehingga dpat disimpulkan bahwa terdapat hubungan antara tingkat pendidikan dengan keladian hipertensi di Pasar Beringharjo Kota Yogyakarta.

Berdasarkan hasil uji analisis menunjukkan bahwa nilai dari correlation coefficient sebesar 0,299 yang berarti antara self efficacy dan kepatuhan minum obat penderita hipertensi memiliki hubungan yang lemah, correlation coefficient yang bernilai positif menandakan sifat hubungan yang searah yang berarti jika self efficacy semakin tinggi maka kepatuhan minum obat juga akan semakin tinggi. 
Dalam penelitian ini ditemukan satu data ekstreem yaitu pada kode responden 015. Data ekstreem ini didapatkan setelah dilakukan konversi data kedalam z-score dimana didapatkan nilai -3.06914 pada self efficacy dan 2.88756 pada kepatuhan minum obat. Hasil ini bisa saja terjadi karena kurang pahamnya responden tentang penjelasan yang diberikan atau kurang minatnya responden dalam menjawab kuesioner.

Hasil ini didukung oleh penelitian yang dilakukan oleh (Ariyanto, 2016) dengan judul "Hubungan Kepatuhan Minum Obat dengan Tekanan Darah Pasien Hipertensi di Puskesmas Banguntapan 1 Bantul", didapatkan bahwa sebagian besar pasien dengan kepatuhan minum obat kategori tinggi sebanyak 13 responden $(40,6 \%)$ memiliki tekanan darah normal. Pasien dengan kepatuhan minum obat kategori sedang sebanyak 6 responden $(18,8 \%)$ memiliki tekanan darah normal. Pasien dengan kepatuhan minum obat kategori rendah sebanyak 11 responden $(34,4 \%)$ memiliki tekanan darah tidak normal. Hasil uji Korelasi Spearman diperoleh nilai $p$ sebesar $0,000(p<0,05)$ yang berarti terdapat hubungan yang signifikan antara kepatuhan minum obat dengan tekanan darah pada pasien hipertensi.

Menurut peneliti self efficacy yang tinggi akan mendorong seseorang untuk yakin terhadap pengobatan yang sedang dijalani. Keyakinan tersebut akan memotivasi dan meningkatkan harapan seseorang untuk mencapai kesembuhan yang akhirnya mendorong seseorang untuk berperilaku patuh dalam menjalani pengobatan hipertensi.

Hasil ini juga didukung penelitian dilakukan oleh (Okatiranti \& Amelia, 2017) dengan judul "Hubungan Self efficacy dengan Perawatan Diri Lansia Hipertensi". Penelitian tersebut menggunakan 69 sampel lansia yang mengalami hipertensi. Hasil penelitian ini didapatkan bahwa responden yang memiliki self efficacy tinggi dan perawatan dirinya baik sebanyak 28 orang $(80.0 \%)$, sedangkan responden yang memiliki self efficacy rendah dan perawatan dirinya kurang sebanyak 27 orang $(79,4 \%)$. Hasil uji analisis didapatkan nilai p-value 0,000 yang berarti terdapat hubungan self efficacy dengan perawatan diri lansia hipertensi.

Dari hasil uji statistik didapatkan nilai p-value 0,025 yang berarti $<0,05$ sehingga antara self efficacy dengan kepatuhan minum obat penderita hipertensi di wilayah kerja Puskesmas Tejakula 1 memiliki hubungan yang signifikan.

\section{KESIMPULAN DAN SARAN}

\section{Simpulan}

Karakteristik responden di wilayah kerja Puskesmas Tejakula 1 memiliki usia tertinggi yaitu 65 tahun dan usia terendah 27 tahun dengan ratarata usia responden 45,04 tahun.

Karakteristik responden di dilayah kerja Puskesmas Tejakula 1 berdasarkan jenis kelamin didapatkan bahwa mayoritas responden berjenis kelamin perempuan yaitu sebanyak 29 orang $(51,8 \%)$ dan berjenis kelamin laki-laki sebanyak 27 orang $(48,2 \%)$.

Karakteristik responden di wilayah kerja Puskesmas Tejakula 1 berdasarkan riwayat pendidikan didapatkan mayoritas responden memiliki riwayat pendidikan SMP yaitu sebanyak 19 orang $(33,9 \%)$ dan minoritas memiliki riwayat pendidikan Tidak Sekolah dan Perguruan Tinggi yaitu sebanyak 3 orang $(5,4 \%)$.

Hasil uji analisis menunjukkan bahwa nilai dari correlation coefficient sebesar 0,299 yang berarti antara self efficacy dan kepatuhan minum obat penderita hipertensi memiliki hubungan yang lemah. Dari hasil uji statistik didapatkan nilai $p$-value 0,025 yang berarti $<0,05$ sehingga antara self 
efficacy dengan kepatuhan minum obat penderita hipertensi di wilayah kerja Puskesmas Tejakula 1 memiliki hubungan yang signifikan.

\section{Saran}

Hasil penelitian ini dapat digunakan sebagai informasi bagi tempat pelayanan kesehatan guna meningkatkan pelayanan khususnya pelayanan di Wilayah kerja Puskesmas Tejakula 1, sehingga pelayanan kesehatan dapat lebih optimal.

\section{DAFTAR PUSTAKA}

Ariyanto, Y. N. (2016). Hubungan Kepatuhan Minum Obat Dengan Tekanan Darah Pasien Hipertensi Di Puskesmas Banguntapan 1 Bantul. STIKES Jenderal A. Yani Yogyakarta.

Badan Penelitian Dan Pengembangan Kesehatan Kementerian Kesehatan RI. (2013). Riset Kesehatan Dasar 2013. In Kementrian Kesehatan Republik Indonesia. https://doi.org/1 Desember 2013

Dhewi, G. I., Armiyati, Y., \& Supriyono, M. (2012). Hubungan antara pengetahuan, sikap pasien dan dukungan keluarga dengan kepatuhan minum obat pada pasien TB paru di BKPM Pati. Karya Ilmiah.

Hilmi, H., \& Kirnantoro, K. (2014). Gambaran Tingkat Stres pada Lansia yang Menderita Hipertensi di Gandu Sendang Tirto Berbah Sleman Yogyakarta. STIKES'Aisyiyah Yogyakarta.

Ningsih, D. L. R., \& Rosida, L. (2017). Faktor-Faktor yang Berhubungan dengan Kejadian Hipertensi pada Pekerja Sektor Informal Di Pasar Beringharjo Kota Yogyakarta.

Nursalam. (2014). Metodelogi Penelitian Ilmu Keperawatan:
Pendekatan Praktis. Salemba Medika.

Okatiranti, O., \& Amelia, F. (2017). Hubungan Self Efficacy Dengan Perawatan Diri Lansia Hipertensi. KEPERAWATAN, 5(2).

Putu, N. I., \& Rastiti, P. (2019). Hubungan Self Efficacy dengan Perilaku Ibu Melakukan Pencegahan Gizi Kurang pada Balita di Wilayah Kerja Puskesmas Kediri II Tabanan.

Rusnoto, R., \& Hermawan, H. (2018). Hubungan Stres Kerja Dengan Kejadian Hipertensi Pada Pekerja Pabrik Di Wilayah Kerja Puskesmas Kaliwungu. Jurnal Ilmu Keperawatan Dan Kebidanan, 9(2), 111-117.

Shadine, M. (2010). Mengenal Penyakit Hipertensi, Diabetes, Stroke \& Serangan Jantung Pencegahan dan Pengobatan Alternatif. In KEENBOOKS.

https://doi.org/10.1177/109019817 400200403

Triyanto, E. (2014). Pelayanan Keperawatan Bagi Penderita Hipertensi secara Terpadu. In Graha Ilmu.

\section{PROFIL PENULIS UTAMA}

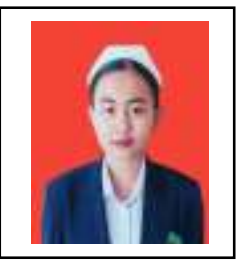

Sang Ayu Kadek Sukmaningsih lahir di Mataram pada tanggal 03 Desember 1998. Penulis lahir dari

Pasangan suami istri Bapak Sang Made Dharma dan Ibu Sang Ayu Ketut Kirti. Penulis Berkebangsaan Indonesia dan beragama Hindu. Kini penulis beralamat di Desa Tanah Aji, Kecamatan Abang, Kabupaten Karangasem, Provinsi Bali.

Penulis menyelesaikan pendidikan dasar di SD Negeri 2 Tiyingtali dan lulus pada tahun 2010. Kemudian penulis melanjutkan di SMP Negeri 1 Abang 
dan lulus pada tahun 2013. Pada tahun 2016, penulis lulus dari SMK Negeri 1 Amlapura. Selanjutnya, mulai tahun 2016 sampai dengan penulis masih terdaftar sebagai mahasiswa Program S1

Keperawatan di Sekolah Tinggi Ilmu

Kesehatan Buleleng.

Penulis:

Sang Ayu Kadek Sukmaningsih, Jurusan

S1 Keperawatan, Sekolah Ilmu

Kesehatan Buleleng.

E-mail: Suksma20199@gmail.com

Penulis Kedua,

widyaputra90@gmail.com

Penulis Ketiga,

nershari@gmail.com

Penulis Keempat,

Windiridayanti@gmail.com 